-ISSN: 2148-0494

dergİabant (AïBÜ İlahiyat Fakültesi Dergisi), Bahar 2020, Cilt:8, Sayı:1, 8:277-297

Geliş Tarihi: 25.02.2020

Kabul Tarihi: 26.05.2020

Araştırma Makalesi

Doi: https://doi.org/10.33931/abuifd.694114

\title{
Bağımsızlık Dönemi Kırgızistan'da Arapça Eğitim ve Öğretimi
}

Fadime Kavak*

Bekzat Asanbekov**

\section{Öz}

Kırgızistan'ın 1991 senesinde bağımsızlığını kazanmasıyla birlikte ülkede siyasi, sosyal, ekonomik ve dini alanda değişiklikler olmuştur. Dine ve Arap diline olan ilginin artmasıyla da hem dinin hem de Arap dilinin öğretildiği medrese ve kurumların yanı sıra dini ve Arapça yayınlarda bir artış gözlenmiștir. İște bu makalede öncelikle Bağımsızlık Dönemi Kırgızistan'da Arapça eğitim ve öğretiminin nasıl başladığı, Arapça'yı Kırgızistan'da öğrenmek isteyenlerin ilk başvuracakları temel kaynakların neler olduğu üzerinde durulmuştur. Daha sonra da Arap dili grameri, belâgat, sözlük ve tercüme alanında yazılan ilk çalışmalar ve onların yöntemlerinden bahsedilmiştir. Ayrıca Arapça eğitimin verildiği üniversiteler, fakülteler, medreseler, yabancı dil merkezleri gibi resmi ve gayri resmî kurumlarla buralarda okutulan başlıca kaynak eserler hakkında bilgi verilmiş; Kırgızistan'ın eğitim sistemindeki Arap dilinin durumu tespit edilmeye çalışılmıştır.

Anahtar Kelimeler: Kırgızistan, Bağımsızlık Dönemi, Arapça Eğitimi, Öğretim Metotları, Başlıca Eğitim Kurumları.

\section{Arabic Education and Teaching During the Independence Period of Kyrgyzstan}

\begin{abstract}
With the independence of Kyrgyzstan in 1991, political, social, economic and religious changes took place in the country. With the increasing interest in religion and the Arabic language, an increase has been observed in the madrasas and institutions where religion and Arabic language are taught, as well as religious and Arabic publications. In this article, firstly, how the education and training of Arabic started in Independence Period in Kyrgyzstan, and what are the main sources that those who want to learn Arabic in Kyrgyzstan will be the first reference. Then, the first studies written in Arabic grammar, rhetoric, dictionary and translation and their methods are mentioned. In addition, information was given about the universities, faculties, madrasas, foreign language centers where Arabic education is provided and the main source works taught there; The situation of the Arabic Language in the education system of Kyrgyzstan has been tried to be determined.

Keywords: Kyrgyzstan, Independence Period, Arabic Education, Teaching Methods, Major Educational Institutions.
\end{abstract}

Doç. Dr., Bursa Uludağ Üniversitesi İlahiyat Fakültesi, Temel İslam Bilimleri Bölümü, Arap Dili ve Belagati Anabilim Dalı, fadimekavak@hotmail.com ORCID ID 0000-0002-8817-4771

** Bursa Uludağ Üniversitesi Sosyal Bilimler Enstitüsü, Temel İslam Bilimleri Anabilim Dalı, bekzatkgz2015@gmail.com ORCID ID 0000-0003-4870-6777 


\section{Giriş}

Kırgızistan'ın bağımsızlığını kazanmasından günümüze kadarki süre içerisinde tüm eğitim-öğretim aşamalarında, Arapça eğitimin verildiğini ve yayıldığını söylemek mümkündür. Bağımsızlık döneminden itibaren kurulan ilk cami ve medreselerle başlatılan Arapça eğitim faaliyeti, SSCB döneminden önce de vardır. Ancak Orta Asya bölgesinde Sovyet komünist rejiminin yerleşmesiyle birlikte Arapça öğretimi ve dinle ilgili eğitim faaliyetleri yasaklanmaya başlamıştır.

31 Ağustos 1991 tarihinde Kırgızistan'ın bağımsızlığına kavuşmasıyla birlikte dini hayatı, ibadetleri ve manevî değerleri öğretecek kurumlarda Arapça eğitimi verme konusunda müslümanlar büyük gayret ve çaba sarf etmişlerdir. Devletin demokratik esaslar üzerine kurulması ve bu bağlamda yeni yasal düzenlemeler getirilmesi halkın çeşitli özgürlükler kazanmasını, özellikle dini eğitim içerisinde Arapça eğitimine başlamasını sağlamıştır. Kırgızistan vatandaşlarının Arapça eğitim ve öğretim ihtiyaçlarını karşılamak için de devlet tarafından Arapça eğitim veren resmi yükseköğretim kurumları olan İlahiyat Fakülteleri, Din Bilimleri Bölümleri, Halkla İlişkiler ve Doğu Araştırmaları fakülteleri kurulmuş, ülke genelinde İslam Enstitüleri, medreseler ve dil merkezleri açılmıştır.

İște bu makalede öncelikle Kırgızistan'da bağımsızlıktan günümüze kadar devam eden sarf, nahiv, belâgat ve sözlük çalışmaları; daha sonra da Arapça eğitimin verildiği kurumlar ve öğretim yöntemleri hakkında bilgi verilmeye çalışılacaktır.

\section{Bağımsızlık Döneminde Yapılan Çalışmalar}

Kırgızistan 31 Ağustos 1991 tarihinde bağımsızlığına kavuşunca, dine ve o dini en iyi en doğru şekilde öğrenmeyi sağlayacak olan Arapça'ya karşı ilgi artmış, bu dili öğrenmek isteyenlere Arapça dersler verilmeye başlanmıştır. Bu çerçevede ilk olarak Tatar dilbilimci Ahmadhâdi Maksudi'nin (1868-1941) hazırladığı "elMu'allimü's-Sânî"1 adlı eseri okutulmuştur. Bu eser, Arap harflerinden başlayıp Kur'ân-ı Kerîm'i öğrenene kadar öğrencilerin ihtiyaç duyduğu her türlü bilgiyi içerdiği için, Arapça öğrenmek isteyenlerin ilk olarak başvurduğu temel kitaplardan biri olmuştur.

Daha sonra Arapça öğrenimini daha da kolaylaştırmak, okuma ve yazma ihtiyacını karşılamak için Kırgızistanlı Aşur Ali Uulu Mavlyan (1975- ...)2 tarafından "Azhariya" isimli eser kaleme alınmıștır. Kırgızistan'da ilk kez Arap dilini ve Kur'ân-ı Kerîm'i öğretmeye yönelik hazırlanan bu eser, her türlü ilme ve bilgiye sahip tüm yaştaki okurlara hitap etmektedir. Dünyanın birçok diline çevrilen bu kitap, İOS programında hazırlanıp tüm dünyada Arapça öğrenmek isteyen herkesin istifadesine sunulmuştur.

Ahmadhâdi Maksudi, el-Mu'allimü's- Sânî (Kazan: y.y., 1917).

Arap ve İngiliz dillerini bilen yazar, Arapça öğrenimine Mısır'ın Kahire şehrinde başlamıştır. 2004 senesinden beri Kırgızistan'da Arapça öğretmenliği yapmaktadır. bk. Aşur Ali Uulu Mavlyan, Salsabilya (Bişkek: Printekspres Yayınları, 2016), 4-5. 
Yazar daha sonra Kur'ân-ı Kerîm'i doğru okumayı öğrenmek isteyenler için tecvit kurallarını ele alan bir eser yazmıştır. Bu eser bir önceki eserin devamı niteliğinde olduğu için onun ikinci cildi olarak yayınlanmıştır. ${ }^{3}$

Zikredilen bu iki temel eser dışında sarf, nahiv ve belâgat alanlarında da hem yukarıda adı geçen yazarların hem de başka ilim adamlarının az da olsa eserleri bulunmaktadır. Bunların yanısıra tercüme faaliyetlerini ve sözlük çalışmalarını da görmek mümkündür.

\subsection{Sarf (Morfoloji) Çalışmaları}

Kırgızistan'da Arap Dili gramerinin kelime yapısını ele alan sarf ilmiyle ilgili bir tane eser vardır. Mısır'da eğitim gören Aşur Ali uulu Mavlyan tarafından yazılan, 2013 senesinde de "Sajida" ismiyle dört cilt olarak yayınlanan bu eser modern ve ilmî bir anlatım tarzına sahiptir. Başlangıçta Rusça yazılan eser, daha sonra Kırgızca'ya çevrilmiştir.

Bu eserin yazılması yükseköğretim kurumlarında okuyan öğrenciler ve kendi kendine temelden Arapça öğrenmek isteyenler için büyük avantaj olmuştur. Çünkü eserin anlatım dilinin Kırgızca olması ve ele alınan konuların şemalarla anlatılması Arap dilinin kısa sürede daha hızlı bir şekilde öğrenilmesini sağlamıștır. Oysa o zamana kadar sarf ilmini öğrenmede ve öğretmede sadece yabancı kaynaklar kullanıldığı için zorluklar yaşanmış, yanlış anlamalar olmuştur. ${ }^{4}$

Eser, Arap dilini karşılaştırmalı gramere dayalı olarak öğretmeyi hedeflemekte; bu yüzden konu anlatımında Kırgız dilindeki fiillerle Arapça'daki fiillerin benzer taraflarına dikkat çekmektedir. ${ }^{5}$ Konuları pekiştirmek için de Kur'ân1 Kerîm, hadisler ve atasözlerinde geçen kelimelere yer vermektedir. Ayrıca kitapta konuların anlatımında kolaydan zora doğru giden bir sistem takip edilmiş; her bir konunun sonunda o konuyu pekiştirmek için alıştırmalar verilmiştir. ${ }^{6}$

Kitaptaki konular günümüzde hazırlanmış olan Arapça-Kırgızca ve ArapçaRusça sözlüklerdeki bâb dizimine benzer şekilde hazırlanmıştır. İlk olarak en çok kullanılan sülasi mezit fiillerin bütün halleri, özellikleri, kullanılışı ve fiillerin tercümesi verilmiş; daha sonra Kur'ân-ı Kerîm ve hadislerden örnekler getirilmiştir.

\subsection{Nahiv (Sentaks) Çalışmaları}

Kırgızistan'ın bağımsızlık döneminde, Arapça gramerinin söz dizimi (sentaks) kuralları ile irab bölümünü kapsayan nahiv alanında yapılan müstakil çalışmalar yok denecek kadar azdır. Bu yüzden genelde Arapça kaynaklardan istifade edilmektedir.

Aşur Ali Uulu Mavlyan, Azhariya (Bişkek: Printekspres Yayınları, 2008), 1/3.

Așur Ali Uulu Mavlyan, Sajida Arap Tili Morfologiya İlimin Üyrönüü Boyunça Okuu Kitebi (Bişkek:

Printekspres Yayınları, 2013), 1/3.

Mavlyan, Salsabilya, 11.

Mavlyan, Salsabilya, 6. 
Son yıllarda Arapça öğrenmek isteyenlerin talebini karşılamak için eğitimini Mısır'da tamamlayan Aşur Ali uulu Mavlyan tarafından "Salsabilya" isimli bir eser kaleme alınmıştır. Özellikle Kırgızistan'da yaşayan ve dini eğitime yeni başlayan herkes için hazırlanan bu eserin dili Rusça'dır. İlk olarak "Uçebnoye posobiye po izuçeniyu gramatiku arabskogo yazıka" (Arapçayı öğrenmek için çalışma kılavuzu) ismiyle Kırgızistan'ın başkenti Bişkek'te 2012 yılında; daha sonra kitaba yeni bilgiler ve konularla ilgili alıştırmalar eklenerek, "Salsabilya Uçebnoye posobiye po izuçeniyu gramatiku arabskogo yazıka" ismiyle 2016 senesinde basılmıştır. ${ }^{7}$

Eserde ilk olarak ismin tarifi yapılmış; daha sonra ism-i işâretlerin kullanılışı, sıfatlar, marifelik-nekrelik, zamirler, renkler, harf-i cerler, cümle çeşitleri, inne ve benzerleri, harf-i cerli fiiller, lâzım ve müteaddî fiiller, irab çeşitleri ve izâfet tamlaması hakkında bilgiler verilmiştir. Her konu önceki konularla ilişkilendirilerek anlatılmıştır. $^{8}$

Eserde konularla ilgili alıştırmaların bulunması, öğrencilerin öğrendikleri konuları uygulamalarına ve pekiştirmelerine olanak sağlamaktadır.

\subsection{Belâgat Çalışmaları}

Kırgızistan'da meânî, beyân ve bedîi içine alan belâgat ilmiyle ilgili bir tane eser vardır. Bu eser, Oş Devlet Üniversitesi'nden mezun olan ve halen Bişkek Sosyal Bilimler Üniversitesi'nde öğretim üyesi olarak görev yapan Doç. Dr. Momunaliev Kadır tarafından yazılmıştır. Müellif "Kırgız cana Arap tilindegi salyștıruulardın lingvostilistikalık tabiyatı" ismini verdiği ve 2008 senesinde bir cilt olarak yayınlanan kitabında, ilk defa Arap belâgati ile Kırgız edebiyatının benzer yönlerini karşılaştırarak ele almıştır.

Eserde her iki dilin bilgi kaynakları, yapısı, edebiyatı karşılaştırmalı olarak ele alınmış; birbirine benzer yönlerine ve birbirinden ayrıldıkları noktalara değinilmiştir. Bu durumu açıklamak için de Manas destanından, Kırgız yazarlardan C. Balasagın'ın, Cenicok'un, Toktogul'un, Barpının, T. Ümötaliev'in, A. Osmonov'un, A. Ömürkanov'un yazılarından; İmruülkays (ö. 540 dolayları), Buhtürî (ö. 284/897), Mütenebbî (ö. 354/965), Ahmed Şevkî (1868-1932) vb. Arap yazarların, şairlerin nazım ve nesirlerinden örnekler verilmiştir. ${ }^{9}$

\subsection{Sözlük Çalışmaları}

Moğol istilasından önce Arap hilafetinin Orta Asya halklarının yaşadığ bölgelere gelmesiyle birlikte Arapça kelimeler Türk dillerine girmeye ve halk tarafından kabul görmeye başlamıştır. Böylelikle tarihten günümüze kadar geçen zaman zarfında pekçok kelime Kırgızca'ya geçmiştir. Ancak bu kelimeler ağızdan

Aşur Ali Uulu Mavlyan, Uçebnoye Posobiye po İzuçeniyu Gramatiku Arabskogo Yazıka (Bişkek: Printekspres Yayınları, 2016), 1.

Mavlyan, Salsabilya, 1-9, 13-20, 23-25, 28-30, 34, 43, 58-70.

Kadır Momunaliev, Kırgız Cana Arap Tilindegi Salyștıruulardın Lingvostilistikalık Tabiyatı (Bişkek: Bişkek Gumanitardık Universiteti, 2008), 1-3. 
ağıza aktarılırken bazen harflerin söylenişi değişmiş, bazen de kelimeler gerçek anlamının dışına çıkmıștır. ${ }^{10}$

Uzun zamandan beri ihtiyaç duyulan ilk Arapça-Kırgızca sözlük 2008 yılında ortaya çıkmıştır. Sözlük, o zamanlar milletvekili olan Alişer Sabirov'un teşvikiyle ve Kırgızistan üniversitelerinde çalışan dilci ve mütercim akademisyenlerin ${ }^{11}$ katkılarıyla altı senede hazırlanmıştır. Sözlügü hazırlama ekibinde olan Ahmad Kalandarov ilmi, tıbbi ve teknoloji terimlerinin Kırgizcasının olmaması sebebiyle Rusça olarak verildiğini dile getirmiştir.

Sözlükte Arap dilinin kelime hazinesi mümkün olduğunca Kırgızca'ya çevrilmeye çalışılmıştır. Bu sözlük çalışması Kırgızistan tarihinde bir ilk olduğu için herkesi memnun etmiştir. Çünkü büyük bir tarihe sahip olan Kırgız halkı İslam'ı kabul ettikten sonra Arapça kelimeleri anlamaya ve kendi dilinin kelime hazinesine katmaya çalışmıştır. Örneğin, K.K. Yudahin'in Kırgızca-Rusça sözlüğünde 2177 Arapça kelime bulunmaktadır. ${ }^{12}$

\subsection{Tercüme Çalışmaları}

İlmi müesseseler ve bazı şahıslar tarafından Arapça kitapların Kırgızca ve Rusça'ya tercüme edilmesi, Arap dilini öğrenmede kolaylık sağlamıştır. Ancak tercüme eden kişinin kabiliyetine ve her iki dile vakıf olmasına göre tercümenin kalitesi de değişmiştir.

Kırgızistan'da ilk tercüme çalışması Kur'ân-ı Kerîm'in mealine yöneliktir. Alauddin Mansur başkanlığında yedi sene süren heyet çalışması 2001 senesinde tamamlanmıștır. ${ }^{13}$ Daha sonra Kırgızistan Müslümanları Dini İdaresi tarafından 2006 senesinde meal tercümelerinin en iyisi olarak kabul edilen bir Kur'ân-ı Kerîm meali hazırlanmıştır. Bu meal çalışması Sadıbakas Doolov, Abdışükür İsmailov, Düyşön Abdıldaev ve Sadık Gavay tarafından yürütülmüştür. Bu meal Dünya Müslüman Gençlik Meclisi'nin Kırgızistan temsilcisi Said Bayumi'nin desteğiyle 2007 senesinde bir cilt halinde on bin adet basılmıştır. ${ }^{14}$

Bir başka tercüme de "Akıl-es, Ruh ve İman" vakfı müdürü ve "Koom cana üy bülöö" gazetesinin başkanı Düyşön acı Abdılda uulu tarafından İmam Nevevî’nin Kırk Hadis isimli eserinin Kırgızca'ya çevrilmesidir. Bu tercüme hem bütün okuyucular hem de okullarda, medreselerde ve yükseköğretim kurumlarında eğitim

10 İbragim Malsagfov vd., Arapça-Kırgızça Sözdük (Bişkek: İzbasma Yayınları, 2006), 5.

11 Beşeri Bilimler tercüme bürosu müdürü Malsagfov İbragim Aliyeviç, Kusein Karasyev adındaki Bişkek Beşeri Bilimler Üniversitesi Doğubilim ve Uluslararası ilişkiler Fakültesi okutmanı Kalandarov Mederbek Koşubakoviç, İșenalı Arabaev adındaki Kırgız Milli Üniversitesi Yabancı Diller Yüksek Okulu öğretmeni İdirisov Mederbek Koşubakoviç, Kusein Karasyev adındaki Bişkek Beşeri Bilimler Üniversitesi Doğubilim ve Uluslararası ilişkiler Fakültesi okutmanı Mambetov Nurdin Canışbekoviç, Turdubayeva Ayzada Camgırçieva ve Ceenbek kızı Madina'dır. bk. Malsagfov vd., Arapça-Kırgızça Sözdük, 5.

12 Konstantin Kuzmiç Yudahin, Rusça-Kırgızca Sözlük (Moskova: Sovetskaya Ensklopediya Basması, 1965).

13 Alauddin Mansur, Iyık Kur'ân (Bişkek: y.y., 2001).

14 Abdışükür İsmailov vd., Iyık Kur'ân Maanilerinin Kototrmosu (Bișkek: Erkam Yayınları, 2006). 
gören öğrencilerin "iman" adı verilen dersi için hazırlanmıştır. Bu kitaba Kırgızistan Müslümanları Dini İdaresi tarafından izin verilmiștir.

Daha sonra 2010 senesinde İmam Nevevî'nin önemli çalışmaları arasında yer alan "Riyâzü's-sâlihîn min hadîsi seyyidi'l-mürselîn" adlı eseri Sayid Bayumi'nin desteğiyle, Sadık Gavay tarafından Arapça'dan Kırgızca'ya tercüme edilmiştir. Bu çalışma "Assanbel" vakfı tarafından basılmıştır. ${ }^{15}$

\section{Kırgızistan'da Arapça Eğitimi Veren Kurumlar}

Orta Asya Türk Devletleri içerisinde \% 99,8 okuma-yazma oranına sahip Kırgızistan'da 1497 okul öncesi, 130 ilkokul (1-4. sinıflar), 195 ortaokul (59.sınıflar), 1922 lise (10-11.sinıflar), 51 yükseköğretim kurumu ve 102 medrese vardır. Diğer Türk Cumhuriyetleri'nde olduğu gibi Kırgızistan'da da eğitim devlet tarafından yapılırken 1992'de çıkarılan yeni kanunlarla özel okul ve üniversitelerin de eğitim vermesine izin verilmiştir. ${ }^{16}$

Kırgızistan'da Arapça eğitimi yabancı dil olarak kısmen ilkokul, ortaokul ve liselerde, çoğunlukla da medreseler, üniversiteler ve dil merkezlerinde verilmektedir. Arapça eğitimin verildiği bu kurumlar şunlardır:

\section{1. Üniversiteler ve Fakülteler}

Kırgızistan'da 51 yükseköğretim kurumu bulunmakta olup bunların 34'ü devlete ait diğer 17 'si ise özeldir. ${ }^{17}$

Kırgızistan'ın çeşitli üniversitelerinde Doğu Araştırmaları, Hukuk, Uluslararası İlişkiler ve Arap dili eğitimi için açılan fakültelerde Arapça okutulmaktadır. Bunlara ek olarak Kırgızistan'da dini eğitim vermekte olan İlahiyat fakültelerinde de Arapça dersleri yer almaktadır. ${ }^{18}$

Kırgızistan'da Arapça eğitimi verilen ve yabancı dil olarak Arapça'nın okutulduğu başlıca üniversite ve fakülteler şunlardır:

\subsubsection{Mahmud Kaşgari Barskani Doğu Üniversitesi}

Kırgız Cumhuriyeti'nin mevzuatına uygun olarak eğitim sistemini geliştirmek, onu uluslararası standartlara yakın hale getirmek, uluslararası programlar çerçevesinde yükseköğretim kurumlarıyla iş birliği yaparak çeşitli alanlarda yüksek nitelikli uzmanlar yetiştirmek için kurulmuştur. ${ }^{19}$

15 Mahmud İsmail İbrahim ez-Zâhirî, Târîhu'l-Lugati'l-'Arabiyye fî Kırgızistan (Bişkek: y.y., 2016), 878.

16 İdealsas Yurtdışı Eğitim Danışmanlı̆̆ı, "Kırgızistan'da Lisans ve Önlisans Eğitimi Fırsatları" (Erişim 15.09.2016).

17 Kırgız Cumhuriyeti Ulusal İstatistik Komitesi, "Eğitim Kurumlarının Sayısı" (Erişim 30 Mayıs 2020).

18 Hasan Dam, "Kırgızistan'da Yüksek Din Öğretiminin Problemleri Üzerine Bir İnceleme”, OŞ Devlet Ünıversitesi İlahiyat Fakültesi İlmi Dergisi 20/21 (2015), 32.

19 Super İnfo, "Mahmut Kaşgari Doğu Üniversitesi” (Erişim 19 Aralık 2018). 
İlk olarak 20 Nisan 1998 yılında Kırgız-Kuveyt Üniversitesi adıyla kurulan bu kuruma, 2004 yllında Mahmut Kaşgari Barskani Doğu Üniversitesi ismi verilmiştir. ${ }^{20}$ Bu üniversite devlete ait değil, özel bir kurumdur. Kurumun bünyesindeki en önemli fakültelerden biri Arapça eğitimin verildiği "Arap Dili ve Eğitimi” fakültesidir. Bu fakülte kendi içinde üç bölüme ayrılmıştır: "Arap Dili ve Dilbilim”, "Diller", "Uluslararası İlişkiler ve Sosyal Disiplin". Dört yıllık bir eğitim veren bu fakültede yüksek lisans ve doktora eğitimi de verilmektedir. ${ }^{21}$

\subsubsection{Kırgızistan-Türkiye Manas Üniversitesi}

Üniversite, 30 Eylül 1995'de İzmir'de imzalanan “Türkiye Cumhuriyeti ile Kırgızistan Cumhuriyeti hükümeti arasında Kırgızistan'ın başkenti Bişkek'de Kırgızistan-Türkiye Manas Üniversitesi'nin kurulmasına dair anlaşma"nın her iki ülkenin yetkili makamları tarafından onaylanmasını müteakiben 1997-1998 öğretim yılında eğitim vermeye başlamıştır. ${ }^{22}$

2014-2015 Eğitim-Öğretim dönemi Güz Yarıyılı itibariyle 9 fakülte, 4 Yüksekokul ve 1 Meslek Yüksekokulu'nda 4891 lisans ve önlisans, 2 enstitüde ise 243 yüksek lisans ve doktora öğrencisi öğrenim görmüştür.

2011-2012 eğitim-öğretim yılında da üniversiteye bağlı olarak İlahiyat Fakültesi açılmıştır. Bu fakülte hazırlık senesi dâhil olmak üzere beş yıl eğitim vermektedir. Eğitim dili Türkçe ve Kırgızca olup bu diller hazırlık sınıfında öğretilmekte; Arapça ise yabancı dil olarak eğitim-öğretim süresi boyunca ağırlıklı bir şekilde gösterilmektedir. ${ }^{23}$

Fakültede Din Bilimleri ve İslam Bilimleri olmak üzere iki bölüm bulunmaktadır. Bu iki bölümde birinci yarıyılda "Arap Dili I", daha sonraki yarıyıllarda da "Arap Dili II, III, IV, V, VI, VII, VIII" adı altında her dönem zorunlu ders olarak haftada beș saat okutulmaktadır. Dersi veren hoca ise Suriyeden gelen ve Kırgızistan vatandaşlığını alan Abdulbasit Kraij hocadır.24

\subsubsection{Bişkek Sosyal Bilimler Üniversitesi}

Sosyal bilimler alanında önde gelen ve yükseköğretim kurumları arasında lider bir üniversitedir. Eğitim dünyanın onaltı dilinde (İngilizce, Almanca, İtalyanca, Japonca, Çince, Korece, Arapça, Rusça vb.) yürütülmektedir. Her sene beşyüzden fazla öğrenci farklı ülkelerde uluslararası değişim programlarına katılmaktadır.

Üniversitede Arapça eğitimi verilen Doğu Bilimleri ve Uluslararası İlişkiler Fakültesi'nde üç bölüm vardır. Bunlardan birincisi "Uluslararası İlişkiler Uzmanlığı",

ez-Zâhirî, Târîhu'l-Lugati'l-'Arabiyye fî Kırgızistan, 420.

Emil Turgunbaev, "Mahmut Kaşgari Doğu Üniversitesi" (Erişim 2016).

Kırgızistan-Türkiye Manas Üniversitesi, "Tarihçe” (Erişim 05 Ağustos 2017).

Dam, "Kırgızistan'da Yüksek Din Öğretiminin Problemleri Üzerine Bir İnceleme", 32;

Kırgızistan-Türkiye Manas Üniversitesi, "Tarihçe".

24 ez-Zâhirî, Târîhu'l-Lugati'l-'Arabiyye fî Kırgızistan, 566. 
ikincisi "Linguistik", üçüncüsü de "Doğu Bilimleri" bölümüdür. Bu bölümlerde lisans derecesinde dört senelik eğitim verilmektedir. ${ }^{25}$

\subsubsection{Orta Asya Amerika Üniversitesi}

1993 yılında kurulan üniversite, Orta Asya'nın demokratik dönüşümü için geleceğin liderlerini yetiştiren, Amerikan liberal sanat geleneğinde uluslararası, çok disiplinli bir öğrenim topluluğudur. Müfredatı Hazırlık Programı (Yeni Nesil Akademisi), ondört lisans ve dört yüksek lisans programı içerir. Üst düzey akademik programlarına ek olarak da ifade özgürlügü, eleștirel düşünme ve akademik dürüstlük taahhüt eder. Orta Asya Amerika Üniversitesi, dünya çapında birçok üniversite ve kuruluşla ortaklıklarını sürdürmektedir. ${ }^{26}$

Üniversitede modern yabancı diller programı çerçevesinde Arapça yabancı dil olarak okutulmaktadır. Arapça eğitimi verilirken de okuma, yazma, konuşma becerilerinin gelişmesine, sözlü ve yazılı metin çevirisine, sözlük kullanımına önem verilmiştir. $^{27}$

\subsubsection{Kırgız-Rus Slav Üniversitesi}

Kırgız-Rus Slav Üniversitesi, Kırgız Cumhuriyeti ve Rusya Federasyonu'nun iş birliği ile 1993 yılında Bişkek'de açılmıştır.28

İleri derecede dil eğitimi vermeyi hedefleyen üniversitede, Avrupa ve Doğu Dilleri bölümü yer almaktadır. Arapça eğitimi de bu bölümde verilmektedir. $\mathrm{Bu}$ dilleri yetkin öğretim üyeleri vermektedir. Mezun olan öğrenciler iki yükseköğrenim diploması yani Kırgızistan Cumhuriyeti ve Rusya Federasyonu diploması almaktadır. ${ }^{29}$

\subsubsection{Cusup Balasagın Kırgız Millî Üniversitesi}

Cusup Balasagın'ın adını taşıyan mevcut Kırgız Milli Üniversitesi'nin kuruluş kökleri 1932 yılında kurulan Kırgız Devlet Pedagoji Enstitüsü'ne dayanmaktadır. Mayıs 2002'de Kırgız Cumhuriyeti Cumhurbaşkanı'nın yeni bir kararnamesiyle, ulusal yükseköğrenim kurumu Kırgız Milli Üniversitesi kurulmuştur. Üniversitenin bünyesi altında lisans düzeyinde eğitim veren Doğu Araştırmaları Fakültesi yer almaktadır. Fakülte kendi içinde "Doğu Araştırmaları ve Afrika Çalışmaları", "Siyaset, Doğu'nun Siyasi Süreçleri", "İslam Araştırmaları" ve "Diller Arası İletişim ve Doğu Edebiyatı" gibi bölümlere ayrılmaktadır.

Dört yıllık akademik ve bilimsel bir program sunan fakülte Çince, Japonca, Korece, Farsça ve Arapça gibi dilleri bilen kişiler yetiştirmektedir. Bunun yanısıra

\footnotetext{
25 Bişkekskiy Gosudarstvenniy Universitet "Bişkekskiy Gosudarstvenniy Universitet imeni K. Karasaev" (Erișim 12 Haziran 2018).

Orta Asya Amerika Üniversitesi (AUCA), "Tarihçe” (Erişim 12 Mart 2016).

Orta Asya Amerika Üniversitesi (AUCA), "Arabic for Beginners I" (Erișim 16 Ekim 2016).

Kırgız-Rus Slav Üniversitesi (KPCY), "Tarihçe” (Erişim 2013).

ez-Zâhirî, Târîhu'l-Lugati'l-'Arabiyye fî Kırgızistan, 566.
} 
üniversitede dört yıllık eğitim veren Yabancı Diller Fakültesi de yer almaktadır. Bu fakültenin bünyesinde de Arapça eğitimi verilmektedir. ${ }^{30}$

\subsubsection{Arabaev Üniversitesi}

Önceleri "Kırgız Devleti Pedagoji Enstitüsü" adını taşıyan kuruma, 03.05.2005 tarihinde Kırgızistan Cumhuriyeti Cumhurbaşkanı'nın kararıyla "Arabaev Kırgızistan Devlet Üniversitesi” ismi verilmiştir. ${ }^{31} 2007$ yllında da bu üniversitenin bünyesindeki Doğu Çalışmaları ve Diplomasi Fakültesi, Doğu Çalışmaları ve Uluslararası İlişkiler Fakültesi'ne dönüştürülmüştür. Fakülte öğrencilerine iki yabancı dil eğitimi vermektedir. Bunlardan birincisi doğu dilleri (Çince, Korece, Japonca, Farsça, Arapça, Türkçe) diğeri de İngilizcedir.

Ayrıca 2008 yılında Sosyal Bilimler Enstitüsü tarafından enstitüye bağlı olarak İşenalı Arabaev Devlet Üniversitesi İlahiyat Fakültesi kurulmuştur. Bu fakülte daha sonra 2010-2011 yılında enstitünün bünyesinden çıkıp bağımsız bir kurum olarak eğitim vermeye başlamıştır. ${ }^{32}$

\subsubsection{S. Naamatov Narın Devlet Üniversitesi}

1996 yılında kurulan Narın Devlet Üniversitesi'nin rektörü Profesör A. A. Akmatalyev'in girişimi ile ilk olarak 2005 yılında Narın Devlet Üniversitesi ortak bilim ve eğitim alanında işlerini yürütmek için Mahmut Kaşgari Barskani adlı Doğu Üniversitesi ile iş birliği yapılmış ve üniversite bünyesinde "Arap Dili ve Kültür Merkezi" açılmıştır. Bu merkezin açılmasından itibaren merkezi geliştirme, ders kitaplarının temini ve bütün eğitim şartlarının sağlanması için Mahmut Kaşgari Barskani adlı Doğu Üniversitesi'nden mezun olan ve bu merkezde eğitim veren Mamıtov Syezbek isimli kişi sayesinde 2007 yılında Uluslararası Gençlik Meclisi'nin Kırgızistan'daki temsilcisinin desteği ile kurumun her türlü ihtiyacı karşılanmış, yeni teknolojilerden istifade edilmiştir. ${ }^{33}$

Daha sonra gençlere Arap dili ve medeniyetini tamamıla öğretmek amacıyla 2007 yılında "Arap Dili ve Edebiyatı” bölümünü açmak için Eğitim Bakanlığı'ndan lisans alınarak, Narın Devlet Üniversitesi'nin Fen Fakültesi bünyesi altında "Doğu Araştırma ve Arap Dili Bölümü” açılmıştır. Bölümde Mahmut Kaşgari Barskani adlı Doğu Üniversitesi'nden mezun olan Mamıtov Syezbek ve Abakirov Kubanıçbek isimli hocalar ders vermektedir. ${ }^{34}$

Cusup Balasagın Kırgız Millî Üniversitesi, “Tarihçe” (Erişim 23 Ekim 2013).

Toktorbek Ömürbekov, Kırgız Tarihi (Bişkek: Kırgızistan Yayınları, 2003); İşenalı Arabaev Adını Taşıyan Kırgız Devlet Üniversitesi, "Tarihçe” (16 Mayıs 2016).

32 Timur Kozukulov, "Kırgızistan'da Dini Kurumsallaşma ve Toplum”, A Üniversitesi Sosyal Bilimler Enstitüsü Dergisi 1/1 (2015), 203.

Satıbaldı Naamatov Narın Devlet Üniversitesi, “Tarihçe” (Erişim 10 Haziran 2017).

Satıbaldı Naamatov Narın Devlet Üniversitesi Arap Dili ve Madaniyat Borboru, "Tarihçe" (Erişim 21 Şubat 2017). 


\subsubsection{Oş Devlet Üniversitesi}

Oş Devlet Üniversitesi, 1939 yılında ilk olarak "Oş Öğretmen Enstitüsü" ismiyle açılmıştır. Daha sonra 1951 yılında "Oş Pedagoji Enstitüsü" ismiyle hizmet veren ve beş fakülteden oluşan bu kurum, 1992 yılında da Kırgız Cumhuriyeti Cumhurbaşkanı Kararnamesi ile "Oş Devlet Üniversitesi”ne dönüştürülmüştür. Onaltı fakülte ve altı enstitüden oluşan bu üniversite, bağımsızlık dönemindeki en büyük eğitim kurumudur. ${ }^{35}$

Üniversitede Arapça eğitimi verilen üç bölüm vardır. Bunlardan birincisi "Uluslararası İlișkiler Uzmanlığı" bölümüdür. Bu bölüm uluslararası ilișkiler alanında nitelikli uzmanların eğitilmesini, diplomatik ve konsolosluk hizmetlerini, bölgesel çalışmalarda uzmanlaşmayı ve iki yabancı dili içerir. Uluslararası İlişkiler alanında öğrenim gören öğrenciler için ilk yabancı dil İngilizce, ikinci dil ise doğu dillerinden (Çince, Korece, Japonca, Arapça, Farsça ve Türkçe) birisidir.

Arapça eğitimi verilen ikinci bölüm; Türkiye Diyanet Vakfı'nın finanse ettiği, Ankara Üniversitesi ile Oş Devlet Üniversitesi arasında imzalanan bir protokolle kurulan ve 1993 yllında açllan “Oş İlahiyat Fakültesi”dir. Daha sonra bu fakülteye bağlı olarak 2003 yılında Bişkek'de bir sivil toplum kuruluşu tarafından finanse edilen "Araşan Sosyal Bilimler Enstitüsü İlahiyat Fakültesi” açılmıştır.

Üçüncüsü de Siyaset Bilimi ve Doğu Araştırmaları bölümüdür.

$\mathrm{Bu}$ üç bölüm dışında üniversiteye bağlı olan ve sadece Arapça eğitimin verildiği kurs niteliğindeki "Adis" isimli dil merkezi, 19.12.2012 yılında Oş Devlet Üniversitesi'nin rektörü tarafından açılmıştır. Merkezin hedefi toplumda profesyonel uzmanlar yetiştirmektir. ${ }^{36}$

\subsubsection{Kırgızistan İslam Üniversitesi}

İlk olarak 1991'de medrese olarak inşa edilen, 1993 yılında da Kırgızistan Müslümanları Dini İdaresi'ne bağlı bir kurum olan Hazreti Ömer İslam Enstitüsü’ne dönüştürülen Kırgızistan İslam Üniversitesi, 25 Nisan 2003 yılında üniversite statüsüne sahip olmuştur. ${ }^{37}$ Şu an üniversitede içlerinde doktor, doçent ve profesörlerin de bulunduğu yaklaşık yetmiş akademisyen görev yapmaktadır. Hem Kırgızistan'ın farklı bölgelerinden hem de diğer ülkelerden gelen sekiz yüzden fazla öğrenci de bu üniversitede eğitim görmektedir. ${ }^{38}$

Kırgızistan İslam Üniversitesi "İlahiyat ve Fen", "Arap Dili" ve "Şeriat" olmak üzere üç bölümden oluşmaktadır. Arap dili uzmanlığında eski usul medrese hocaları

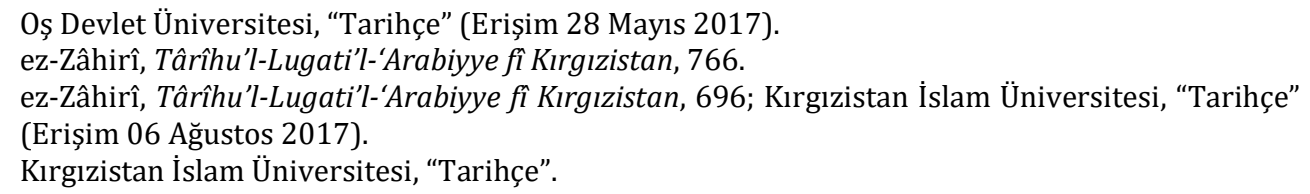


ile birlikte yerli ve Arap ülkelerinden gelen doktorlar, yardımcı doçentler, doçentler ve profesörler ders vermektedir. ${ }^{39}$

\subsubsection{Kırgızistan Uluslararası Üniversitesi}

1993 tarihinde kurulan Kırgızistan Uluslararası Üniversitesi; Kırgız Cumhuriyeti Eğitim ve Bilim Bakanlığı, Kırgız Cumhuriyeti Dışişleri Bakanlığı ve Kırgız Cumhuriyeti Ulusal Bilimler Akademisi tarafından kurulmuştur. Ayrıca San Francisco Devlet Üniversitesi (ABD) üniversitenin gelişimine destek vermiștir.

1997 yılında bu üniversitede Yabancı Diller Fakültesi kurulmuştur. Şu anda, bu fakültenin ismi "Dilbilim ve Bölgesel Çalışmalar" fakültesi olarak değiştirilmiştir. Üniversitenin diğer bölümleriyle karşılaştırıldığında, hala oldukça genç bir fakülte olarak kabul edilebilir. Fakültede dört yıl boyunca lisans derecesinde Arap dili dersleri verilmektedir. Buradan mezun olan öğrenciler de tercüman olarak çalışmaktadır. Öğrencileri "Dilbilim" ve "Bölgesel Çalışmalar" alanlarında yetiştirmeyi amaçlayan bu fakülte, dilbilim alanında pratik amaçlı yabancı dilleri (İngilizce, Çince, Arapça, Japonca, İtalyanca ve Türkçe) temel bilgilerden başlayarak iyi derecede öğretmeyi, aynı zamanda öğrenilen dillerin ana dilleri ile sözlü ve yazıll, doğrudan ve ters çeviri, ticari ve gayri resmi iletişim becerilerini profesyonel standartlara yaklaștırmaya gayret göstermektedir. ${ }^{40}$

\subsubsection{Isık-Köl Devlet Üniversitesi}

Kırgızistan'ın doğusunda Isık-Köl bölgesinin Karakol şehri merkezinde yer almaktadır. Ülkenin en geniş eğitim kurumlarından biri olan üniversite, 13 Haziran 1940 tarihinde iki yıllık bir öğretmen enstitüsü olarak kurulmuştur. 1941 yılında da Frunze Öğretmenler Enstitüsü ile birleştirilmiştir. 1953 yılında Öğretmen Enstitüsü Prizhevalsk Devlet Pedagoji Enstitüsü olarak değiştirilmiştir.

1992'de Kırgızistan'ın bağımsızlığa kavuşmasından sonra Enstitü üniversite statüsüne sahip olmuş ve üniversiteye Kırgız halkının ilk profesörü olan dilbilimci Kasım Tınıstanov'un (1901-1938) ismi verilmiştir.

Üniversite bünyesindeki Rus Filoloji ve Yabancı Diller Fakültesi'nin tarihi, üniversitenin kurulmasından sonra 1959'da açılan Rus Dili ve Edebiyatı Bölümü'ne dayanmaktadır. 1998 yılında Yabancı Diller Fakültesi olarak, daha sonra da Dünya Dilleri ve Bütünleştirici İlişkiler Merkezi olarak adı değiştirilmiştir. 1999 yılında İngilizce, Almanca ve Fransızca bölümleriyle Merkez Yabancı Diller Enstitüsü'ne dönüştürülmüştür. 2002'den itibaren enstitü yabancı dil fakültesi statüsüne geri dönmüş ve 2008 yılında Rus Filoloji ve Yabancı Diller Fakültesi olarak yeniden adlandırılmıștır. Fakültede şu an Rus Dili ve Edebiyatı, Yabancı Diller, İngiliz Dili ve Öğretim Yöntemleri, Çin ve Arap Dilleri gibi bölümler bulunmaktadır.41

Kırgızistan İslam Üniversitesi, "Tarihçe”.

Uluslararası Kırgızistan Üniversitesi, "Tarihçe” (Erişim 2017).

Isık-Köl Devlet Üniversitesi, "Tarihçe”, (Erişim 2017). 
288 | Fadime Kavak - Bekzat Asanbekov

\section{Kırgızistan'da Arapça eğitimi verilen ve yukarıda adı geçen üniversitelerde okutulan başlıca kaynak eserler şunlardır: ${ }^{42}$}

\section{a. Dili Arapça Olan Eserler}

1. Sabri Hauli, Suat Hauli, Abu Uvays Mahmud, "Takallum".

Dili Arapça olan ve beş kitaptan oluşan bu eser Mısır'da basılmıştır. Beş kitabın tümü de üniversitelerde okutulmaktadır.

2. Abdurrahman b. İbrahim el-Fevzân, Muhtâr et-Tâhir Huseyn, Muhammed Abdulhâlık Muhammed, Muhammed b. Abdirrahmân Âlu'ş-Şeyh, "el-Arabiyye beyne yedeyk".

Üç ciltten oluşan bu eser, Suudi Arabistan'da basılmış olup tamamı üniversitelerde okutulmaktadır.

3. Ali el-Abdu başkanlığındaki komisyon, "Silsiletü Ta'limi'l-Arabiyye Li gayri'n-nâtıkıyn bihâ.

Dört kitaptan oluşan ve Bişkek'te basılan bu eserin tümü üniversitelerde okutulmaktadır.

4. Dr. F. Abdurrahîm "Durûsü'l-Lugati'l-Arabiyye li gayri'n-nâtıkîn bihâ".

Dört kitaptan oluşan eser, üniversitelerde tercih edilen kaynaklardandır.

\section{b. Dili Rusça Olan Eserler}

1. B. M. Grande "Kurs arabskoy grammatiki", Moskova, 2001.

2. A. A. Kovalev, G.Ş. Şarbatov, "Uçebnik arabskogo yazıka", 3 cilt, Moskova,1998.

3. Mahmûd Ziyad, Pravila arabskoga yazıka $v$ oblogçennoy b upornoy forme, 2009

Orjinali Arapça olan “Kavâ'ldü'l-Lugati'l-Arabiyye” isimli bu eser, iki ciltten oluşmaktadır. İki cildi de Rusça'ya çevrilen eserin sadece birinci cildi üniversitelerde okutulmaktadır.

4. S. A. Kuzmin "Uçebnik arabskogo yazıka", Moskova, 2001.

5. Abdelhamid Algarbavi, "Arap etişterin cöndöö boyunca okuu kuralı", Kasablanka-Marokko, 2008.

6. Sayed İzzat, Diologdor, Bişkek, 2017. Rusça'dır.

Orjinali Arapça olan ve tek kitaptan oluşan "el-Hıvâr" isimli bu eserin dili

Üniversite ve fakültelerde okutulan bu eser isimleri üniversitelerden bizzat istenmiş ve tarafımıza ulaşmıștır. 
7. B. Z. Halidov "Uçebnik arabskogo yazıka", Taşkent, 1977.

8. H. K. Baranov, "Arabsko-Russkiy slovar", Moskova, 2000.

9. V. M. Borisov "Russko-Arabskiy slovar" Moskova, 1998.

10. Mingalaev A.K., Şayhulin T.A., "Grammatika arabskogo yazıka. Uöebnoye posobiye", Kazan, 2001.

11. V. E. Şagal, F.S.Zabirov, M.N.Merekin, "Uçebnik po arabskomu yazıku" Moskova, 1983.

12. Aşur Ali uulu Mavlyan, "Sajida" 4 cilt, Bişkek 2013.

Bu eserler dışında Arapça öğrenmek isteyenlerin faydalanabileceği başlıca Arapça, Kırgızca ve Rusça internet siteleri şunlardır:

1. https://www.aljazeera.com/

2.http://islamtoday.ru/islam_v_mire/arabskij_mir/sajty_dlya_izucheniya_ar absk

3. http://www.arabic.ru/about/links.html

4. http://www.albawaba.com "Аль-баваба"

5. http://www.naseej.com "Насидж"

6. http://www.ayna.com "Эйна?"

7. www.fundarabist.ru

8. maximsitnikov.ru/arabic.shtml

9. https://po-arabski.ru

\subsection{Medreseler}

Bağımsızlık dönemi Kırgızistan'da hem dini hem Arapça okuma yazmayı öğrenmek isteyenlerin ilk başvurdukları kurumlardan biri medreselerdir. Kırgızistan'ın çeşitli bölgelerinde toplam yüziki medrese bulunmaktadır. Bu medreseler, ekonomik ve başka sebeplerden dolayı diğer ülkelerdeki vakıflar veya cemaatlerin desteğiyle inşa edilmiştir. Medreseler özel dini eğitim kurumları olmakla birlikte Kırgızistan Müslümanları Dini İdaresi'nde hazırlanan ve Âlimler Meclisi'nin kararnamesiyle gerçekleştirilen eğitim programı ile eğitimlerini sürdürmektedirler. Bu kurumlarda ikibin beşyüz civarında öğrenci öğrenim görmektedir. ${ }^{43}$

Şu an Kırgızistan'da Arapça'nın ve şerîi ilimlerin okutulduğu 16 tane iki senelik ilk seviyede, 17 tane üç senelik orta düzeyde, 26 tane de dört senelik yüksek seviyede eğitim veren medreseler vardır. Bu medreselerin ortak eğitim programı Kırgızistan Müslümanları Dini İdaresi tarafından hazırlanmaktadır. Bu üç farklı

43 Suat Cebeci, Kırgızistan'da Dini Durum ve Din Eğitimi (Bişkek: y.y., 2014), 36. 
seviyedeki medreselerde sarf, nahiv, Arap dili (Pratik Arapça), belâgat, hüsni hat ve edebiyat adı altında Arapça eğitimin verildiği dersler vardır. Bu derslerde okutulan bazı kitaplar aynı olmakla birlikte bazıları farklılık göstermektedir.

Eğitim süresi iki yıl olan başlangıç seviyesindeki medreselerde okutulan başlıca eserler şunlardır:

Sarf derslerinde; Mu'allimu's-Sarf, Mebdeü's-Sarf, Bidân ve Sarfı Mîr;

Nahiv derslerinde; Harekât, en-Nahvu'l-Vâdıh, ed-Durûsü'n-Nahviyye, Mietü Âmil, Hidâyetü'n-Nahv ve Nahvi Mîr;

Arap dili (Pratik Arapça) derslerinde de el-Lugatü'l-Arabiyye.

Orta düzeyde eğitim verilen medreselerde okutulan başlıca sarf, nahiv ve Arap dili derslerine ait kitaplar da şöyledir:

Sarf derslerinde; Mu'allimu's-Sarf, Mebdeü’s-Sarf, Bidân, Sarfı Mîr ve İlmu'sSîga.

Nahiv derslerinde; Harekât, en-Nahvu'l-Vâdıh, ed-Durûsü'n-Nahviyye, Nahvi Mîr, Mebdeü'n-Nahv, Mietü Âmil, Hidâyetü'n-Nahv ve Kâfiye.

Arap dili (Pratik Arapça) derslerinde el-Lugatü'l-Arabiyye.

Yüksek seviyede eğitim veren medreselerde ise sarf, nahiv, Arap dili derslerinin yanısıra belâgat, edebiyat ve hüsnü hat dersleri de verilmektedir.

Sarf derslerinde; Tafsîl Ekmelî, İlmu's-Sîga, Mîzân, Mu'allimu's-Sarf, Mebdeü's-Sarf, Bidân, Sarfı Mîr;

Nahiv derslerinde; Harekât, en-Nahvu'l-Vâdıh, ed-Durûsü'n-Nahviyye, Nahvi Mîr, Mebdeü'n-Nahv, Mietü Âmil, Hidâyetü'n-Nahv, Kâfiye, Şerhu Câmi' ve Elfiyye;

Arap dili (Pratik Arapça) dersinde el-Lugatü'l-Arabiyye;

Belâgatta; Durûsü'l-Belâga, Telhîs, Muhtasaru'l-Meânî;

Edebiyat derslerinde; Unvânü'l-Beyân, Makâmâtü'l-Harîrî, Mesnevî, Sûfi Allahyar ve Humâsî adlı eserler okutulmaktadır.

Hüsn-i hat dersinde Kur'ânî, Nesh, Nastalîk ve Rik'a gibi yazı türlerinin yazılışı ve okunuşu öğretilmektedir. ${ }^{44}$

Her üç seviyedeki medreselerde okutulan Arapça eserler ve yazarları aşağıdaki tabloda toplu bir şekilde gösterilmiştir:

44 Kırgızistan Müslümanları Din Başkanlığı, "Yüksek Öğretim Kurumlarının Birleşik Müfredatı" (Erişim 2017.) 


\begin{tabular}{|c|c|}
\hline Sarf Kitapları & Yazarları \\
\hline Mu'allimu's-Sarf (معلم الصرف) & أحمد هادي مقصودي \\
\hline Mebdeü's-Sarf (مبدأ الصرف) & صنعة الله بيكبولاط \\
\hline \multicolumn{2}{|l|}{ Bidân (بدان) } \\
\hline Sarfı Mîr (صرف مير) & 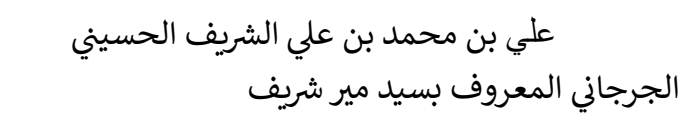 \\
\hline İlmu's-Sîga (علم الصيغة) & أحمد الكاكوروي \\
\hline Tafsîl Ekmelî (تفصيل أكملي) & $\begin{array}{l}\text { Mulla Akmalhon ibn Mulla } \\
\text { Yusufhon Toşkandi }\end{array}$ \\
\hline Mîzân (ميزان) & شيخ يعقوب القاسمي \\
\hline Nahiv Kitapları & Yazarları \\
\hline \multicolumn{2}{|l|}{ Harekât (حركات) } \\
\hline en-Nahvu'l-Vâdıh (النحو الواضح) & علي الجارم ، مصطفى أمين \\
\hline $\begin{array}{l}\text { ed-Durûsü'n-Nahviyye } \\
\text { (الدروس النحوية) }\end{array}$ & - مصطفى طموم \\
\hline Nahvi Mîr (نحو مير) & الجرجاني المعروف بسيد مير شريف علي الشريف الحسيني \\
\hline Mebdeü'n-Nahv (مبدأ النحو) & صنعة الله بيكبولاط \\
\hline Mietü Âmil (مائة عامل ) & عبد القاهر الجرجاني \\
\hline Hidâyetü'n-Nahv (هداية النحو) & محمد بن يوسف بن علي (أبو حيان النحوي) \\
\hline Kâfiye (كافية) & 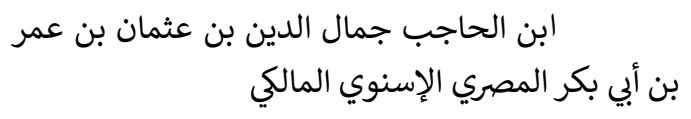 \\
\hline Şerhu Câmi“ (شرح جامع) & عبد الغفور بن صلاح اللاري الانصاري \\
\hline Elfiyye (ألفية) & محمد بن عبد الله بن مالك \\
\hline Arap Dili Kitabı & Yazarları \\
\hline
\end{tabular}




\begin{tabular}{|c|c|}
\hline (Pratik Arapça) & \\
\hline el-Lugatü-l Arabiyye (اللغة العربية) & \\
\hline Belâgat Kitapları & Yazarları \\
\hline Durûsü’l-Belâga (دروس البلاغة) & - مصطفى طموم حفني ناصف - محمد دياب - سلطان محمد \\
\hline Telhîs (تلخيص) & محمد بن عبد الرحمن القزويني جلال الدين \\
\hline $\begin{array}{l}\text { Muhtasaru'l-Meânî } \\
\text { (مختصر المعاني) }\end{array}$ & سعد الدين التفتاز اني \\
\hline Edebiyat Kitapları & Yazarları \\
\hline Unvânü'l-Beyân (عنوان البيان) & بن محمد الشبراوي الشافي الأزهر جمال الدين أبي محمد عبدِ الله \\
\hline $\begin{array}{l}\text { Makâmâtu'l-Harîrî } \\
\text { (مقامات الحريري) }\end{array}$ & محمد الحريري البصري \\
\hline Mesnevî (مثنوي) & جلال الدين الرومي الري \\
\hline Sûfi Allahyar (صوفي الله يار) & Sûfi Allahyar \\
\hline Humasî (خماسي) & \\
\hline \multirow[t]{2}{*}{ Hüsn-i hat } & Yazı türleri \\
\hline & Kur'ânî, Nesh, Nastalîk, Rika. \\
\hline
\end{tabular}

\subsection{Okullar}

\subsection{1. "Davha" Okulu}

2003 yılında inşa edilen okulda, iki dilde (Arapça ve İngilizce) eğitim verilmektedir. Okulun kapsamlı bir ders programı ve ders dişı etkinlikleri vardır. Okulda nitelikli hocalar ders vermektedir.

Okulda bulunan dil merkezi birinci sınıf Avrupa ses ve görüntü ekipmanları ile donatılmıştır. Okulun amacı hem fiziksel hem ahlâki açıdan sağlıklı, yetkin, eğitimli ve donanımlı bireyler yetiştirmektir. ${ }^{45}$

45 Davha, "Davha Okulu” (Erişim 2016). 


\subsection{2. "Salsabıl" Kız Okulu}

Kız öğrenciler için açılan ilk ve orta öğretimin verildiği bir kurumdur. Bütün öğretim kadrosu bayandır. Yabancı dillerin derinlemesine öğretilmesi için İngilizce, Arapça özel bir program uygulanmaktadır. ${ }^{46}$

\subsection{3. "Naima" Genel Eğitim Müslüman Okulu}

Bişkek'teki en iyi özel ortaokullardan biri olarak kabul edilir. Eğitim, yüksek pedagojik eğitime ve geniş deneyime sahip öğretmenler tarafından Devlet Eğitim Standardı'na göre yapılır.

Okul 2015 yılında erkeklerden ayrı eğitim verilmesi için kurulmuştur. Okulun programı, hem devlet okulu onaylı bir sertifika hem de tam teşekküllü bir İslâmî eğitim almayı mümkün kılan normal okul müfredatını ve dini disiplinleri bir araya getirmekte, genel eğitim programının konularına ek olarak derin bir şekilde Arapça, Kur'ân-ı Kerîm ve İslâmî eğitim vermektedir.47

\subsection{Yabancı Dil Merkezleri}

\subsubsection{Ala-Too Geliştirme Merkezi}

2009 yllında kurulan "Ala-Too Geliştirme Merkezi" kamu vakfl, Kırgızistan'da kamu hayatının eğitim ve gelişiminde yeni fikirlere, ortaklara, tüm olumlu değişimlere açık, dinamik ve sistematik olarak gelişmekte olan bir sivil toplum örgütüdür.

Vakıf temelinde, kişisel odaklı öğrenmeye önem vermekte, derslerde de bilgisayar donanım ve bilişim hizmetlerini kullanmaktadır. Arapça dil kursu, dili öğrenmek isteyen herkesin seviyesine göre tasarlanmış, bu yüzden kursta seviye sınıfları oluşturulmuştur. ${ }^{48}$

\subsubsection{Kırgız-Arap Eğitim Merkezi}

"Kırgız-Arap Eğitim Merkezi” 24.04.2014 yılında Nasirdin Isanov İnşaat, Ulaştırma ve Mimarlık Kırgız Devlet Üniversitesi'nde açılmıştır.

Merkez, eğitim sürecini yürütmek için son derece modern görsel-işitsel teknolojik araçlarla donatılmıştır. Eğitim merkezinde ders veren eğitmenler de Arap dilbilimi alanında eğitim görmüş uzmanlar ve Arap ülkelerinden gelen hocalardır. Bu merkezden mezun olan kimseler de şu anda pekçok Arap ülkesindeki elçiliklerde görev yapmaktadır.49 


\subsubsection{Arabistan Kültür ve Eğitim Merkezi}

Kırgızistan Cumhuriyeti Suudi Arabistan Krallığı Büyükelçiliği ile Kırgızistan Cumhuriyeti Kültür, Enformasyon ve Turizm Bakanlığı'nın desteğiyle, 24 Şubat 2016 tarihinde Kırgız Cumhuriyeti Alykul Osmonov adlı Milli Kütüphane'de Suudi Arabistan Kültür ve Eğitim Merkezi'nin açılıș töreni yapılmıştır.

Merkez, Suudi Arabistan'ın bilgi ve bilimsel kaynaklarına erişimi sağlayacak, bu ülkenin tarihini, geleneklerini ve bilimsel mirasını tanımaya yardımcı olacak ve Arap dilinin derinlemesine öğretilmesine katkıda bulunacaktır. ${ }^{50}$

\section{Kırgızistan'da Arapça Öğretim Yöntemleri}

Dil öğreniminde en önemli unsurlardan biri öğretim yöntemleridir. Eğer öğretim yöntemleri iyi olursa öğrencinin dile olan ilgisi artar ve o dili öğrenmesi daha kolay hale gelir. Kırgızistan'da Arapça eğitim ve öğretim yöntemleri üniversite ve diğer eğitim kurumlarına göre değişmektedir. Bu kurumlardaki başlıca öğretim yöntemleri şöyledir:

\section{1. Üniversitelerdeki Öğretim Yöntemleri}

Kırgızistan'da Arap dili öğretimi genelde dersi veren hocaya göredir. Dersi veren hoca Arapça'yı eski usul (medrese usulü) ile öğrenmişse derslerinde o yolu takip eder; eğer yeni metotla eğitim görmüş ise o yöntemle dersini anlatır.

Bütün üniversitelerde Arap dili eğitimi dört yıldır. İlk iki yıl “Hazırlık Arap Dili", son iki yıl da "Genel Edebî Arap Dili” okutulmaktadır. İki yıllık Hazırlık Arap Dili eğitiminde okuma, imlâ, sarf-nahiv, sözlü-yazılı anlatım ve Pratik Arapça dersleri yer almaktadır. Genel Edebî Arap Dili'nde ise metin üzerinden belâgat dersleri verilmektedir. Bazı üniversitelerde eğitim süreci görsel araçlar, multimedya ses ve video sistemleriyle desteklenmektedir.

Dersler hocanın tek taraflı anlatımı, soru-cevap yöntemi ve alıştırmaların çözümü şeklinde gerçekleşmektedir. Öğrencilerin kelime hazinesini zenginleștirmek için de metin okumaları yapılmaktadır. Bunların yanısıra öğrenciler hem bireysel hem de grupla çalışma yapmaya yönlendirilmektedir.

Her dönemde ara sınav ve final sınavı yapılmaktadır. Ara sınav $\% 40$, final $\%$ 60 etkilidir. Dört yılın sonunda da öğrencilere diploma verilmektedir.51

\subsection{Medreselerdeki Öğretim Yöntemleri}

Medreselerde dersler, müderrisin seçmiş olduğu kitabın takip edilmesi tarzında işlenmektedir. Okunan kitapların hemen hepsi, daha önce yaşamış âlimler tarafından kaleme alınmış, klasik Arapça eserlerdir.52

50 Eliana-Maryam Satarova, "Suudi Arabistan Kültür ve Eğitim Merkezi Bișkek”, Umma Dergisi (Erişim 3 Şubat 2016).

51 ez-Zâhirî, Târîhu'l-Lugati'l-'Arabiyye fî Kırgızistan, 425; BGU Üniversitesi, "Tüşündürmö Kat", (Erişim 2018). 
Medreselerdeki öğretim süresi hazırlık sınıfı dâhil beş yıl olarak kabul edilmektedir. Bu programı beş yıldan önce bitirenler olduğu gibi daha geç bitirenlerin de bulunması, sınıf geçme yerine ders/kitap geçme sisteminin varlığını ortaya koymaktadır. ${ }^{53}$

Medreselerde soru-cevap metodu kullanılmaktadır. Hoca öğrencilere soru sorup cevabını beklediği gibi, öğrenciler de belirli bir nizama göre hocaya soru sorabilmektedir. ${ }^{54}$

Medreselerdeki öğretim genellikle müşahede, tecrübe, tetkik ve tenkide yer vermeyen, sadece ayetlerin, hadislerin veya diğer metinlerin șerh ve tefsirine dayanan bir metotla gerçekleștirilmektedir. Dersler ayet ve hadislerin yorumlanmasının hoş görülmediği bir anlayışla okutulmaktadır. ${ }^{55}$

\subsection{Yabancı Dil Merkezlerindeki Öğretim Yöntemleri}

Özel bir kurum olan Yabancı Dil Merkezlerinde seviye grupları vardır. İlk seviyede Arap harfleri, bu harflerin nasıl birleştirilip okunacağı ve harekeler üzerinde durulmaktadır. Orta seviyede temel sarf ve nahiv bilgisi; ileri seviyede de ileri derecedeki sarf ve nahiv kuralları öğretilmektedir. Toplam ders süresi dokuz, her seviyenin süresi üç aydır. Haftada üç gün ders vardır. Dersler blok olup doksan dakika sürmektedir.

Merkeze gelen öğrenci ilk önce seviye sınavına tabi tutulur, daha sonra seviyesine göre bir sınıfa yerleştirilir. ${ }^{56}$ Merkezlerde okuma anlama, dinleme ve konuşma dersleri yer almaktadır. Bu derslerin işleniş tarzı da şöyledir: Dersi veren hoca öncelikle konuyu anlatır. Daha sonra öğrenciler tarafından anlaşılmayan bir husus varsa tekrar açıklama yapar. Her dersten sonra da konunun pekiştirilmesi amacıyla ev ödevleri verilir. Ertesi gün yeni derse başlamadan önce de yapılan ödevler hoca tarafından kontrol edilir. ${ }^{57}$

\section{Sonuç}

Sovyetler Birliği'nden ayrılıp bağımsızlığına kavuşan Kırgızistan'da Arapça eğitim ve öğretimi mümkün olduğunca yaygınlaşmış, bu alanda birçok yükseköğretim kurumu, medrese ve yabancı dil merkezi açılmıştır. Devlet üniversitelerindeki İlahiyat Fakültelerinde, Doğu Araştırmaları Bölümlerinde, Uluslararası İlişskiler Bölümlerinde ve Kırgızistan Müslümanları Dini İdaresi tarafından kurulan medreselerde Arap dili ders olarak okutulmaya başlanmıştır. Çünkü yıllarca Sovyetler Birliği yönetiminde kalan Kırgızistan'da bağımsızlık dönemine kadarki süre içinde resmi olarak Arapça eğitimi hiç verilmemiştir.

\footnotetext{
52 Salih Pay - M. Akif Kılavuz, "Kırgızistan'da Bir Din Eğitimi Kurumu: Medreseler”, Uludağ Üniversitesi İlâhiyat Fakültesi Dergisi 18/1 (2009), 267.

53 Pay - Kılavuz, "Kırgızistan'da Bir Din Eğitimi Kurumu: Medreseler”, 267.

54 Pay - Kılavuz, "Kırgızistan'da Bir Din Eğitimi Kurumu: Medreseler”, 270.

55 Pay - Kılavuz, "Kırgızistan'da Bir Din Eğitimi Kurumu: Medreseler”, 270.

56 ez-Zâhirî, Târîhu'l-Lugati'l-'Arabiyye fí Kırgızistan, 746.
} 
Kırgızistan bağımsız olduktan sonra halkın büyük çoğunluğunun Müslüman olması ve dine olan ilginin artması sebebiyle Arapça okuma yazmayı öğrenmek isteyenlerin sayısı çoğalmıştır. Arap ülkeleriyle olan resmi görüşmeler sayesinde de Mısır, Ürdün, Suriye ve diğer Arap ülkelerine gidip Arapça eğitim alma firsatları oluşmuştur. Ayrıca kardeş ülke olan Türkiye'deki İlahiyat fakültelerine ve medreselere gidip Arapça öğrenme imkânı doğmuştur.

Arapça eğitimi için Kırgızistan'dan bu ülkelere giden öğrenciler başlangıçta zorluk çekseler de İslam dinine ve Arapça'ya olan ilgilerinden dolayı en iyi şekilde öğrenim görerek ülkelerine dönmüşler ve Kırgızistan'daki eğitim kurumlarında dersler vermeye başlamışlardır. Ayrıca kendi ülkelerindeki gençlerin ilgi ve kabiliyetine göre yeni öğretim metotları geliştirmişlerdir. Elbette bu alanda gelişme olmakla birlikte eksiklikler de vardır. Mesela medreselerde eğitim okuma yazmaya dayalı olduğu için, buralarda eğitim görenler kendilerini Arapça olarak ifade etmede ve iletişim kurmada zorluk çekmektedirler. Bunun yanısıra sadece pratik Arapça'yı öğrenenler de klasik Arapça kaynaklarını okuyup anlamada zorlanmaktadırlar. Bu yüzden daha sonraki dönemlerde bu iki sorunun çözülmesi için çalışmalar yapılması gerekmektedir.

Kırgızistan'da Arapça eğitim ve öğretimi için son dönemlerde yazılan eserler çok az sayıda olsa bile Arapça öğrenmeye yeni başlayanlar için yeterli sayılabilir. Ancak daha sonra bu alanda geniş çapta çalışmalar yapılması, eserlerin yazılması ve tecrübeli uzman eğitimcilerin yetiștirilmesi gerekmektedir.

\section{Kaynakça}

Ala-Too Geliştirme Merkezi. “Tarihçe”. Erişim 2017. http://alatoocenter.kg/o-фонде/.

AUCA, Orta Asya Amerika Üniversitesi. "Arabic for Beginners I". Erişim 16 Ekim 2016. https://www.auca.kg/ru/auca_at_a_glance/

AUCA, Orta Asya Amerika Üniversitesi. "Tarihçe". Erişim 12 Mart 2016. https://www.auca.kg/en/auca_history/

Bişkekskiy Gosudarstvenniy Universitet. "Bişkekskiy Gosudarstvenniy Universitet imeni K. Karasaev". Erişim 12 Haziran 2018. http://www.bhu.kg/home/about-us.

Cebeci, Suat. Kırgızistan'da Dini Durum ve Din Eğitimi. Bişkek: y.y., 2014.

Cusup Balasagun Kırgız Millî Üniversitesi. "Tarihçe". Erişim 23 Ekim 2013. https://www.knu.kg/ky/index.php.

Dam, Hasan. “Kırgızistan'da Yüksek Din Öğretiminin Problemleri Üzerine Bir İnceleme”. OŞ Devlet Ünıversitesi Illahiyat Fakültesi İlmi Dergisi 20/21 (2015), 29-39.

Emil Turgunbaev. "Mahmut Kaşgari Doğu Üniversitesi". Erişim 2016. http://www.chygysh.kg/about.html.

Davha. "Davha Okulu". Erişim 2016. http://davha.kg/video/

İdealsas Yurtdışı Eğitim Danışmanlığı. "Kırgızistan'da Lisans ve Önlisans Eğitimi Fırsatları". Erişim 15 Eylül 2016. https://www.idealsas.com/Universite-Egitimi/KirgizistandaUniversite.

İşenalı Arabaev Adını Taşıyan Kırgız Devlet Üniversitesi. “Tarihçe”. Erişim 16 Mayıs 2016. http://arabaev.kg/index.php.

Isık-Köl Devlet Üniversitesi. “Tarihçe”. Erişim 2017. http://main.iksu.kg/\%d1\%84. 
İsmailov, Abdışükür vd.. Iyık Kur'ân Maanilerinin Kototrmosu. Bişkek: Erkam Yayınları, 2006.

Kanal Alif. "Bir Müslüman Okulu Bişkek'te En İyi Eğitimi Veriyor". Erişim 2017. https://alif.tv/musulmanskaya-shkola-daet-luchshee-obrazovanie-v-bishkeke/.

Kırgız Cumhuriyeti Ulusal İstatistik Komitesi. "Eğitim Kurumlarının Sayısı”. Erişim 30 Mayıs 2020. http://www.stat.kg/kg/opendata/category/279.

Kırgızistan İslam Üniversitesi. "Tarihçe”. Erişim 6 Ağustos 2017. http://www.kiu.kg.

Kırgızistan Müslümanları Din Başkanlığı. "Yüksek Öğretim Kurumlarının Birleşik Müfredatı". Erişim 2017. https:/muftiyat.kg/birdiktuu-programma.

Kırgızistan-Türkiye Manas Üniversitesi. "Tarihçe". 5 Ağustos 2017. http://manas.edu.kg/index.php/kurumsal/tanitim/tarihçe.

Kozukulov, Timur. "Kırgızistan'da Dini Kurumsallaşma ve Toplum”. Ağrı İbrahim Çeçen Üniversitesi Sosyal Bilimler Enstitüsü Dergisi 1/1 (2015), 177-209.

KPCY, Kırgız-Rus Slav Üniversitesi. "Tarihçe". Erişim 2013. https://krsu.edu.kg/sveden/index.html.

Maksudi, Ahmadhâdi. el-Mu'allimü's-Sânî. Kazan: y.y., 1917.

Malsagfov, İbragim vd.. Arapça-Kırgızça Sözdük. Bişkek: İzbasma Yayınları, 2006.

Mansur, Alauddin. Iylk Kur'ân. Bişkek: y.y. 2001.

Mavlyan, Aşur Ali Uulu. Azhariya. 2 cilt. Bişsek: Printekspres Yayınları, 2008.

Mavlyan, Aşur Ali Uulu. Sajida Arap Tili Morfologiya İlimin Üyrönüü Boyunça Okuu Kitebi. 4 cilt. Bişkek: Printekspres Yayınları, 2013.

Mavlyan, Aşur Ali Uulu. Salsabilya. Bişkek: Printekspres Yayınları, 2016.

Mavlyan, Aşur Ali Uulu. Uçebnoye Posobiye Po İzuçeniyu Gramatiku Arabskogo Yazıka. Bişkek: Printekspres Yayınları, 2016.

Momunaliev, Kadır. Kırgız Cana Arap Tilindegi Salyştıruulardın Lingvostilistikalık Tabiyatı. Bişkek: Bişkek Gumanitardık Universitesi, 2008.

Ömürbekov, Toktorbek. Kırgız Tarihi. Bişkek: Kırgızistan Yayınları, 2003.

Oş Devlet Üniversitesi. "Tarihçe". Erişim 28 Mayıs 2017. http://www.oshsu.kg/univer/?lg=1\&id_parent=5502

Pay, Salih - Kılavuz, M. Akif. "Kırgızistan'da Bir Din Eğitimi Kurumu: Medreseler”. Uludağ Üniversitesi Illâhiyat Fakültesi Dergisi 18/1 (2009), 247-278.

Satarova, Eliana-Maryam. "Suudi Arabistan Kültür ve Eğitim Merkezi”. Umma Dergisi. Erişim 3 Şubat 2016.

http://ummamag.kg/ru/news/439_v_bishkeke_otkrylsya_centr_kultur y_i_izucheniya_saudovskoi_aravii.

Satıbaldı Naamatov Narın Devlet Üniversitesi Arap Dili ve Madaniyat Borboru. "Tarihçe". Erişim 21 Şubat 2017. http://nsu.kg/?page_id=135.

Satıbaldı Naamatov Narın Devlet Üniversitesi. "Tarihçe”. Erişim 10 Haziran 2017. http://nsu.kg/?page_id=323.

Strong. "Salsabıl Kız Okulu". Erişim 2017. http://www.strong.kg/features-mainmenu47/shkola-dlya-devochek-salsabil.html

Super İnfo. "Mahmut Kaşgari Doğu Üniversitesi”. Erişim 19 Aralı 2018. https://www.super.kg/mobile/article/show/31409.

Uluslararsı Kırgızistan Üniversitesi. "Tarihçe”. Erişim 2017. http://iuk.kg/ale/about-us.

Yudahin, Konstantin Kuzmiç. Rusça-Kırgızca Sözlük. Moskova: Sovetskaya Ensklopediya Basması, 1965.

Zâhirî, Mahmud İsmail İbrahim. Târîhu'l-Lugati'l-'Arabiyye fî Kırgızistan. Bişkek: y.y., 2016. 